\title{
Educational games and grade 8 students' academic performance in English
}

\author{
Alcanse, Ana Marie Joy A. $\triangle \triangle$ \\ Laguna College of Business and Arts, Philippines (anamariejoyalcanse001@gmail.com) \\ Recillo, Maria Luisa B. \\ City College of Calamba, Philippines
}

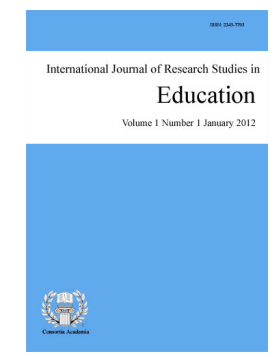

ISSN: 2243-7703 Online ISSN: 2243-7711

Received: 2 August 2021 Available Online: 5 August 2021

\section{Abstract}

This research study determined the effectiveness of educational games in language learning of Grade 8 students in English. In this study, the researcher used quantitative methods with descriptive approach as its research design. The respondents of the study were the forty-eight (48) Grade 8 students of Saint Benilde International School SY 2020-2021. They were selected to comprise the sample using the purposive sample technique. Findings revealed a significant relationship between the level of effectiveness of educational games in language learning and the Grade 8 students' performance as shown in the probability value of .044 which is less than the level significance .05; thus, the null hypothesis is rejected. Therefore, a compendium of educational games that can be used as learning tools in English must be developed. Educational games are very effective in the teaching and learning of language to Grade 8 students; that the teachers had a different perspective of the effectiveness of educational games in language teaching: they are more convinced that the games help improve the language skills of the students. The students, on the other hand, are a little apprehensive in totally accepting the use of games in language learning for they consider games as activities done for fun and entertainment and have not yet taken them as a serious part of their academics; that the tools teachers use in language teaching affect the performance of their students; the more interactive and fun the tools are, the better the students learn; and that a compendium of educational game that can be used as learning tools in English has been developed and ready for dissemination.

Keywords: language, educational games, treatment condition, performance, skills 


\section{Educational games and grade 8 students' academic performance in English}

\section{Introduction}

The English language plays a very important role in the lives of both native and non-native speakers. Students who are non-native speakers learn the English language as a second language. But learning a second language is never easy. Aside from the fact that English language learners often face different challenges, students of the Millennial Generation have imbibed various learning styles and have adopted a different attitude toward the learning process. These realities require modern pedagogical paradigms and trends in education (Kiryakova, 2014) in order to fulfill the students' requirements, needs, and preferences and to keep them engaged and motivated during their learning process. Teachers are therefore challenged to use different teaching methods, approaches, and strategies that allow students to be active participants with strong motivation and engagement with their own learning.

One of the concerns emerging in 21 st century education is that teaching and learning today have changed and the processes somehow differ from those in times past. Historically, education mainly focused on the learning of the fundamental skills and content knowledge that covers reading, writing, calculating, history, and science. However, the one thing that matters in effective learning or education today is the ability to employ high order skills consisting of the ability to think through, to solve complex problems, and to interact critically through language (Hang, 2017). This means that learners must gain a mastery of using the language to express their own thoughts and ideas competently.

Hence, language learning has become a challenging and formidable undertaking which causes disappointment among the learners because they have been expected to acquire structural knowledge of the language and sustain their effort to enable them to assimilate and use the target language. Recently, language educators were able to shift the focus of language teaching and learning from merely "individual linguistic skills to the use of language to achieve the speakers' objectives instead, which has been recognized as communicative competence" (Hang, 2017). Such shift of focus has forced the language mentors to look for task-based exercises and practices that immerse the learners in original and imaginative language use. Thus, educators had to find ways to achieve this goal by exploring informal venues that may provide the lacking practice environments. This needs for a language learning environment in which learners can continually practice English in authentic contexts (real-world use) has led many educators to turn to educational games (Krashen, 2012 as cited in Horowitz, 2019).

In the local scene, the researcher observed that the students who lack knowledge of the English language are also automatically not fluent in it resulting to their very low self-esteem. And to help them in their predicament, she thought that one of the more useful strategies to encourage them in learning a foreign language is through the language games. According to Ersoz (2000 as cited in Mubaslat, 2012), games are highly motivating because they are amusing and interesting. They can be used in practicing all language skills and many other types of communication.

Therefore, the researcher was inspired to embark on this study. Doing the research will give her an in-depth understanding of such practices and will be beneficial to the students who will be motivated to become communicatively competent and fluent in using the English language. It will also equip other teachers with the skills, tools, and confidence needed to step out of the routine of skill-and-drill pedagogy to an interactive and multi-modal world of $21^{\text {st }}$ century education. The aim of the games referred here, specifically the language learning games, was to help students to not only use the target language, but also use that target language to discuss and negotiate until they get the desirable results. And most importantly, the researcher conducted the study because she wanted to help the school improve its performance in international assessments of student 
achievement like the Trends in Mathematics and Science Study (TIMSS) which has been conducted every 5 years. The school has been chosen by the Department of Education to represent Laguna in the year 2019. The results have not been announced; nevertheless, in anticipation of another achievement test, the researcher would like to contribute to the improvement of the school's performance in such academic events by introducing a strategy in language teaching and learning to classes that have not used it since the examination questions have always been given in English. Also, the school has been implementing the use of games in almost all subjects (including English that makes use of language games) and school-wide competitions but a study has never been conducted to test its effectiveness. The researcher deemed there has been no better time to do it than now. The study intended to come up with a compendium of educational games that can be used as learning tools in learning English.

The current study is anchored on the following five (5) theories as they are all applicable to the subject of this study on educational games: Constructivism Theory, Experiential Learning Theory, Multiple Intelligence Theory, Collaborative Learning Theory, and Input and Output Hypothesis of Second Language Acquisition. The Constructivism Theory of Lev Vygotsky (1978 as cited in Wijayanti, 2013) is a language theory that may help students in constructing something based on their own understanding. It emphasizes the students' role than the teacher' in that learning is based on context through the learners' interaction with others. The role of the teacher is to ask the students to learn to construct meaning and to assimilate and accommodate the students' prior knowledge and the new ones.

Vygotsky, from the view of socio-cultural perspectives, assumed that the theory came from the theory of language, thought and mediation in the social environment. He believes that learning occurs via construction of meaning in social interaction within cultures and through language; that knowledge is not transferred from teachers to students but constructed in the students' mind. For him, the language classroom should be characterized by the following: its goal is emphasized in collaborative meaning; the role of teacher is as facilitator who monitors the students' thinking; and there is social interaction.

David Kolb's (1964 as cited in Singh, 2013) theory of Experiential Learning, which is based on ideals of active and reflective learning through experiences with the personal involvement of the learner, argues that human beings generate knowledge and meaning from their own experience. Knowledge is actively constructed by learners, but not passively received from the environment that surrounds them or from their teachers. Experiential learning explores the cyclical pattern of learning from experience through reflection and conceptualizing to action and on to further experience.

In English Language Teaching, the experiential approach encourages learners to develop the target language skills through the experience of working together on a specific task. Implementation of this theoretical approach through language games in the classroom will open a new vista for learners to learn language by using it in real context and be able to explain what they are learning and how they are learning and grade themselves as a way to measure their strengths and weaknesses. Language learning will be accelerated when learners are supportively involved in activities cum games which include exposure, participation, internalization and dissemination to provide opportunities for language learning and create an environment to sustain motivation to learn the target language (Brown, 2000 as cited in Singh, 2016).

Howard Gardner's (1983 as cited in Singh, 2016) Multiple Intelligences Theory constitutes a learner-based philosophy which is an approach to characterizing the ways in which learners are unique and to developing instruction to respond to this helps teachers to understand learners in a better and effective way. This theory opens a new door to multiple teaching strategies which can be easily used in language classrooms according to the students' learning style.

The same theory is an excellent tool to enable teachers to adopt learning strategies and create a learning environment that is suitable for each learner. Language learning through games is an approach which a teacher can use in an English classroom to meet the different learning style of the learners at the optimal level. Language 
learning games are developed based on different types of intelligences. Though there are such games which cover not only single learning style but also more than three learning style, like learners must apply linguistic, intrapersonal, and inter-personal intelligences while participating in games. Here learners need to express their own feelings and must consider and respect the feelings of others. In a game where learners need to mime the title of anything for other learners to guess, the bodily kinesthetic and inter-personal intelligences are brought into play.

Collaborative learning theory is both a classroom technique and a philosophy which is largely rooted in Vygotsky's (1978 as cited in Singh, 2016) socio-cultural theory claiming that learning is outcome of social interaction either among students or between students and a teacher, and essentially assists students in advancing through the Zone of Proximal Development or ZPD (Singh, 2016). ZPD is the distance between the actual developmental level as determined by independent problem solving and the level of potential development as determined through problem solving under adult guidance or in collaboration with more capable peers. It talks about the situation people work in a group when they respect each other's views and highlight individual member's contribution and abilities. According to this theory, knowledge is a product of social construction rather than individual construction. It emphasizes on inquiry cum learning process through which learners start to experience created knowledge rather than transmitted one from teacher.

Input hypothesis assumes that comprehensible input is the main factor in Second Language Acquisition as learner's second language development depends on the amount of input that one receives and on level of input according to learner level. According to Krashen (as cited in Singh, 2016), comprehensible input with low affective filter can pave the way for second language acquisition. In other words, if learners are exposed to input in non-stressful or low-stressful situation they will acquire the second language. But there is no role of production or output in this hypothesis. Therefore, learner could get lots of input over years without any production. But it is not enough to lead the learners to be fluent and accurate users of target language. The output hypothesis claimed that while comprehensible input is necessary for second language learning, learners also need opportunities to speak and produce output to restructure their inter-language grammar.

Based on the above-cited theoretical framework, the researcher of the study has conceptualized this study as shown in the figure given below.

INDEPENDENT VARIABLE

\begin{tabular}{|c|c|}
\hline $\begin{array}{c}\text { Application of a Treatment Condition } \\
\text { in Language Learning } \\
\text { (Educational Games) } \\
\text { • paper games } \\
\text { • board games }\end{array}$ & $\begin{array}{c}\text { Academic Performance of } \\
\text { Grade 8 Students in English Academic } \\
\text { - card games } \\
\text { - kinesthetic games } \\
\text { • technology-aided games }\end{array}$ \\
\hline
\end{tabular}

Figure 1: Research Paradigm

In this study, the researcher investigated the impact of educational games on the academic performance of Grade 8 students in English. The paradigm shows the variables of the given study. The independent variable was the set of educational games which included paper games, board games, card games, kinesthetic games, and 
technology-aided games which were played by individuals, pairs, groups, and the class as a whole. On the other hand, the dependent variable included the effect of the treatment condition on the academic performance of Grade 8 students in English before and after the application of the new strategy.

\subsection{Statement of the Problem}

The study aimed to determine the relationship of educational games on the academic performance of Grade 8 students in English. Specifically, it also attempted to answer the following questions:

$>\quad$ How do the following groups of Grade 8 students perform before and after the application of the treatment condition: Treatment Condition Group and Non-Treatment Condition Group?

$>\quad$ Is there a significant difference in the performance of the treatment condition and non-treatment condition group before the application of the educational games; treatment condition group before the application of the educational games and after they were applied; treatment condition group before the application of the educational games and after they were applied; and treatment condition and non-treatment group after the educational games were applied?

$>\quad$ What is the level of effectiveness of educational games in language learning of Grade 8 students in English as assessed by the teachers and students?

$>\quad$ Is there a significant relationship between the level of effectiveness of educational games in language learning and the Grade 8 students' performance after the application of the treatment condition?

$>$ Based on the findings of the study, what compendium of educational games can be used as learning tools in English may be proposed?

\subsection{Hypothesis of the Study}

There is significant relationship between the use of educational games in learning English and the Grade 8 students' performance after the treatment condition.

\subsection{Scope and Delimitations}

It was difficult to include a large area in this small research due to the limited time and resources. The study limited its respondents to the forty-eight (48) Grade 8 English students of Saint Benilde International School, (Calamba) Inc. The study covered the school year 2020-2021. This study concerned itself with the performance status of the forty-eight (48) Grade 8 students in English language acquisition. The primary data for this study were collected from tests. Tests, questionnaires, and game play were conducted on two groups. Moreover, the researcher handled the two classes during the conduct of the study; thus, it was more convenient for the researcher to approach the students to distribute the questionnaires as well as to collect the questionnaires back. The Educational games included in this study were paper games, board games, card games, kinesthetic games, and technology-aided games which were played by individuals, pairs, groups, and the class as a whole.

\section{Review of Related Literature and Studies}

The integration of games in the educational environment has shown positive results in enhancing the learning process (Trybus, 2014). Strategically designed and integrated, games have the potential to increase academic and learning effectiveness. It is known that playing games positively affects various growth: intellectual, social, emotional, motion and language aspects (Khatib, 2010 as cited in Dafalla, 2016). It also helps in building students' character through the effective participation of the student in the activities that are both fun and humorous. Playing also develops intercommunication and enhances pre-reading skills like application and visual differentiation, as well as encouraging the cooperation and participation among the students. 
The findings of the research in the related literature herein reviewed are all relevant to the present study (2020) for the rich information they provided on the topic of the study.

All the following sources dealt on the effective ways of learning language: Savonitti (2018), Castello (2015), Barnard, and McCarthy believed in Krashen's Input and Output Hypothesis of Second Language Acquisition (through sufficient understandable input); Mohammed (2014), Brigeland, Bilulio, and Morison, and Udosen and Ekpo (2016) suggested appropriate teaching methods (active learning); Van De Bogart, Milczynski (2011), Dewing, and Cheney (2017) described an active learning (using multiple intelligences of Gardner); Aljohani (2017), Amineh, Asl (2015), Savonitti (2018), Amr (2012), Mayer, Alkandari (2016), Overby and Jones (2015) mentioned active learning (using constructivist learning); Ambrose, Alkandari (2016), Brickner, Etter, McCarthy (2010), Taylor, Hamdy (2013), and Cox (2019), believed in experiential learning (based on Kolb's theory); Lantz (2010), Hogan, Tudge, Sanchez (2019), Johnson, Adams-Becker, Cummins, Estrada, Freeman, Hall \& Rao (2016) advised collaborative learning (doing tasks together in groups). To the researcher, all these methods describe the language learning technique that this study proposes, that is, the use of language games: it is interactive, reflective, experiential, collaborative, cooperative, competitive, delightful, and meaningful. It means more time is given to the students to process the learning and that they are given many similar practices to perfect the application of the lesson. The researcher agrees that students only learn when they actively participate in the process, when they experience learning by themselves instead of listening about them, and when they have fun while learning.

Wright, Betteridge, Buckby, Zhe (2012), Jacobs, and Klimova (2014) viewed games as meaningful practice of language to improve students' skills in listening, speaking, reading, and writing comprehensively. The researcher believes that this idea cannot have been more timely than now that the world is in the new normal. Thus, teachers should transform how they teach online, especially since online tools and resources present numerous opportunities that teachers and students can take advantage of. Teachers can curate the best online learning resources about their topics and create learning playlists or menus that can make the learning process a personal journey for every student. And there is no better way to do it than utilizing digital educational games.

The present study is unique in the sense that it is the first of its kind to be conducted in Laguna with its participants comprising the forty-eight (48) Grade 8 English students and four (4) teachers of Saint Benilde International School, (Calamba) Inc. Moreover, the educational games included in this study will also come in various forms like paper games, board games, card games, kinesthetic games, and technology-aided games which will be played individually, in pairs, in groups, and as a class.

\section{Method}

In this study, the researcher employed quantitative methods with descriptive approach. The intent of the researcher was to describe the relationship between the study variables. This study consisted of two variables, namely: educational games $(\mathrm{X})$ as the independent variable, and academic performance in English $(\mathrm{Y})$ as the dependent variable. The purpose of descriptive studies is to describe and interpret the current status of individuals, settings, conditions, or events (Metler, 2014). In descriptive research, the researcher is simply studying the phenomenon of interest as it exists naturally; no attempt is made to manipulate the individuals, conditions, or events. Moreover, Stangor (2011) stated that descriptive research is" research designed to provide a snapshot of the current situation". Descriptive studies are useful for describing how one phenomenon is related to another in situations where the researcher has no control over the independent variables, the variables that are believed to cause or influence the dependent or outcome variable.

This study has provided a relatively complete picture of what occurred at a given time. The researcher conducted this study at Saint Benilde International School (Calamba), Inc. from October 05, 2020 until November 05, 2020. Prior to conducting this study, the researcher coordinated with the Junior High School principal. She submitted a letter in addition to discussing the things she would undertake to accomplish the 
purpose of this research. A total of 48 students participated in this study. Within a month, she was able to conduct eight instructional sessions (with two hours each day) with the respondents in which she was able to properly observe the way the treatment condition was applied in language learning. In each session, she integrated different kinds of games which were played individually, in pairs, in groups, and as a class. She applied games wherever it was more effectively used such as in the motivation or assessment phase. The treatment condition applied by the researcher was of great help despite the learning situation of the respondents. Respondents have always been active in class and they also understood their lessons in an immersive way. The results of each of her teachings to the respondents were positive because they were reflected in how they worked enthusiastically and cooperatively in all activities. The positive relationship of the use of the treatment condition in language learning was also seen in the result of the scores obtained by the respondents in the post-test and the survey conducted.

\subsection{Research Instrument}

In this research, the researcher used a test and a survey as instruments for collecting the data. Test was used by the researcher to measure the students' performance in English after teaching language using educational games. It was aimed at finding out the students' achievement after some of them were taught using Educational Games and without Educational Games. Apart from testing the effectiveness of the game and its educational features through the post-test, a survey was administered to get more details for the study. The survey questionnaire was used to gather more information about the students' thoughts and feelings related to the English learning process in the class using educational games. The forty-eight (48) participants from both groups and four (4) teachers were required to choose one answer from a four-point Likert scale for fourteen items inquiring about their interests and evaluation of the effectiveness of educational games in learning English.

\subsection{Respondents of the Study}

The respondents of the research were the Grade 8 students of SBIS. These involved two classes which were composed of forty-eight (48) students during the academic year 2020/2021. The involved classes were VIII A and VIII B both with twenty-four (24) students each. And to come up with a more accurate assessment of the effectiveness of the use of language games in teaching English, the researcher also included four (4) teachers as her additional respondents.

\subsection{Data Gathering Procedure}

Amid the context of enormous challenges with the COVID-19 pandemic, teaching and learning have been moved from face-to-face to online encounters. For the data gathering, the researcher had written a letter of permission addressed to the administrators of the high school department to conduct the study. It was sent online (gmail) to observe social distancing. After getting the necessary permission, the researcher had conducted the following in succession: pre-test, treatment condition, post-test, and surveys.

The researcher had communicated to the Grade 8 respondents through google meet to discuss the importance and objectives of the study, how to answer the pre-test, post-test and survey questionnaire using google forms and sheets in google classroom, and when to retrieve the responses online.

Prior to the application of the treatment condition, a pre-test was sent to all forty-eight (48) respondents through google classroom. The pre-test was consisted of 20-fill-in-the-blank items. The pre-test was designed to take about 10 minutes to administer. The pre-test was administered to both classes at the same time and precautions were taken to prevent copying. After the pre-test, the treatment condition was applied. The class which was given the treatment condition played educational games including paper games, board games, card games, kinesthetic games, and technology-aided games which were played individually, in pairs, in groups, and as a class online. The games were designed by the researcher to facilitate the delivery of the classroom instruction. They were not designed for this study but had been used before in other classes with perceived 
Alcanse, A. M. J., \& Recillo, M. L. B.

positive results. They were like, and adapted from, other classroom games used for grammar learning.

After the classroom instruction through online, the post-test was administered to both groups through google classroom. The post-test was similar with the pre-test in format and content.

After the post-test was administered, the participants were asked to reflect on their experiences in a survey. At the same time, this survey questionnaire was also given to four (4) teachers through gmail. Right after the retrieval of the test and survey through online, the data was recorded and tabulated. Thereafter, it was forwarded to the statistician for the application of statistical treatment.

\subsection{Treatment of Quantitative or Qualitative Data}

The following were the statistical treatments applied in the study using SPSS: The frequency and percent were used to determine the level of academic performance of students in English. The $t$ test independent sample was used to identify the significant difference between the performance of the group. And the $t$ test dependent sample was used to measure the significant difference between before the application of the treatment condition and after its application.

\section{Results and discussion}

The study attempted to determine the level of effectiveness of educational games in language teaching and learning of Grade 8 students in English.

Problem Number 1. How do the following groups of Grade 8 students perform before and after the application of the treatment condition?

\subsection{Performance of the treatment condition group in English before and after the educational games were applied}

Table 1.1 shows the performance of the treatment condition group in English before and after the educational games were applied.

\section{Table 1.1}

Performance of the treatment condition group in English before and after the educational games were applied

\begin{tabular}{lcccc}
\hline \multicolumn{1}{c}{ Indicators } & \multicolumn{3}{c}{ Aefore } & \multicolumn{2}{c}{ After } \\
\hline Beginning & 6 & 25.0 & & \\
Developing & 3 & 12.5 & 2 & 8.3 \\
Approaching Proficiency & 6 & 25.0 & 5 & 20.8 \\
Proficient & 5 & 20.8 & 17 & 70.8 \\
Advanced & 4 & 16.7 & 24 & 100.0 \\
& \multirow{2}{*}{ Total } & 24 & 100.0 & 91.98 Advanced \\
\hline
\end{tabular}

Legend: 74 and Below Beginning, 75 - 79 Developing, 80 -84 Approaching Proficiency, 85 - 89 Proficient, 90 and Above Advanced.

Table 1.1 shows the performance of the treatment condition group in English before and after the educational games were applied. The overall mean of the Pre-test was 80.94 which was interpreted as Approaching Proficiency. There were 6 students who were rated as at the Beginning phase and 4 students were at the Advanced level. The overall mean of the Post-test was 91.98 and was interpreted as Advanced. Thus, majority of the students were rated as at the Advanced level. This implies that educational games can make language learning more effective. Educational games can create an attractive learning environment for students, make learning more interesting, and enable students to learn by doing, thus enhancing students' high-level abilities. This implication is true as games often incorporate logical reasoning, communication, kinesthetic, visual stimulation, and spatial relations. They also include analysis and interpretation of new and old material which makes learning concrete. Furthermore, the hands-on experiences are integral to critical learning, retention,

122 Consortia Academia Publishing (A partner of Network of Professional Researchers and Educators) 
Attitude of engineering students towards engineering drawing: A case study

and recall of information acquired in the process. Games started to be understood as an opportunity to check how the students work in real-time, how to increase their participation and motivation either individually or as a member of a team, as well as part of a lecture improved in terms of effectiveness in learning (Carrasco, Castellanos, and Viloria, 2019). Games maximize the learners' participation in language learning: while playing games, they subconsciously learn the language.

\subsection{The performance of the non-treatment condition group in English before the application of the educational}

games to the treatment condition group and after they were applied

Table 1.2 shows the performance of the non-treatment condition group in English before and after the educational games were applied to the treatment condition group. The overall mean of the Pre-test was 80.94 and interpreted as Approaching Proficiency. There were 6 students rated as at the Beginning level and 4 students were in the Advance level. While the overall mean of Post-test was 87.71 and interpreted as Proficient. There were 11 of the students who were at the Advanced level. Table 1.2 implies that the students have improved in performance in language learning. Engagement level is nothing compared to that of using educational games. In a traditional environment, learners were taught theoretically. They were expected to apply the knowledge effectively. Traditional teaching usually has a fixed structure. And studies have shown that fully structural, teacher-centered methods of instruction put much emphasis on theoretical issues, may not be that effective to increase the students' achievements; unlike educational games that bring children satisfaction, excitement, and escape from tension and anxiety. Likewise, games improve learning and retention of information more.

\section{Table 1.2}

Performance of non-treatment condition group in English before and after the educational games were applied

\begin{tabular}{|c|c|c|c|c|c|}
\hline \multicolumn{2}{|l|}{ Indicators } & \multicolumn{2}{|c|}{ Before } & \multicolumn{2}{|c|}{ After } \\
\hline Beginning & & 6 & 25.0 & & \\
\hline Developing & & 3 & 12.5 & 3 & 12.5 \\
\hline Approaching Proficiency & & 6 & 25.0 & 4 & 16.7 \\
\hline Proficient & & 5 & 20.8 & 6 & 25.0 \\
\hline \multirow[t]{3}{*}{ Advanced } & & 4 & 16.7 & 11 & 45.8 \\
\hline & Total & 24 & 100.0 & 24 & 100.0 \\
\hline & & \multicolumn{2}{|c|}{ 80.94 Approaching Proficiency } & \multicolumn{2}{|c|}{ 87.71 Proficient } \\
\hline
\end{tabular}

Legend: 74 and Below Beginning, 75 - 79 Developing, 80 -84 Approaching Proficiency, 85 - 89 Proficient, 90 and Above Advanced.

The findings also proved that effective teaching and learning require the utilization of appropriate methodologies and pedagogies to meet the needs and demands of students of this present generation and also, to be in line with the varying events in the educational system worldwide (Mohammed, 2014). The act of learning can be overwhelming, tiring, and burdensome for anybody and these results in learners exhibiting certain behavior that hinder learning. Students describe the conventional schooling experience as boring, specifically in language learning, and many of the dropouts in high school attributed them to classes that were not interesting and the lack of motivation to work (Brigeland, Bilulio, and Morison, 2006 as cited in Udosen and Ekpo, 2016). At present, using the right teaching methods are the major concerns in curriculum implementation because it is through these methods that the specific objectives are attained (Mohammed, 2014).

There are a variety of teaching methods that coincide with an active learning pedagogy. To understand what encompasses active learning, it is important to realize that it can be defined in many ways. One-way active learning can be defined is "an effort to make learning authentic" (Van De Bogart, 2009 as cited in Milczynski, 2011). Additionally, it "refers to techniques where students do more than simply listen to a lecture. Students are doing something including discovering, processing, and applying new information" (Van De Bogart, 2009 as cited in Milczynski, 2011).

Moreover, active learning is an approach for in-depth learning that creatively synthesizes and integrates numerous learning methods (Dewing, 2009 as cited in Cheney, 2017). Active learning shifts the focus of instruction from the instructor to the learners. Active learning draws on the principle of multiple intelligences: 
critical reflection, learning from self, and dialogue and shared experiences with others; and skilled facilitation, intentional action, and takes place in the workplace (Dewing, 2009 as cited in Cheney, 2017). Likewise, experiential learning, or active learning, interactive learning, or learning by doing has resulted in positive outcomes. Most experts agree that when students take an active role in the learning process, the student's learning is optimized (Smart \& Csapo, 2007 as cited in McCarthy, 2010). Moreover, experiential learning offers learners the opportunity to monitor their educational progress. The learner is empowered to create, organize, and experience in ways that aid learning (Taylor \& Hamdy, 2013). Thus, supporters of experiential learning believe that it promotes greater interest in the subject material; enhances intrinsic learning satisfaction; increases understanding and retention of course material; develops the desire and ability to be continuous learners; and improves communication and interpersonal, problem solving, analytical thinking, and critical thinking skills of the students (Brickner \& Etter, 2008 as cited in McCarthy, 2010).

Problem Number 2. Is there a significant difference in the performance of the treatment condition and non-treatment condition group before the application of the educational games; treatment condition group before the application of the educational games and after they were applied; treatment condition group before the application of the educational games and after they were applied; and treatment condition and non-treatment group after the educational games were applied?

Table 2 shows the test of significant difference on the performance of the Grade 8 students before and after the application of the treatment condition. Table 2 shows the test of significant difference on the performance of the Grade 8 students before and after the application of educational games. There is no significant difference in the performance of the treatment condition and the non-treatment condition group before the application of educational games.

\section{Table 2}

Test of significant difference in the performance of the grade 8 students

\begin{tabular}{|c|c|c|c|c|}
\hline Variables & T test & $\mathrm{p}$ value & Remarks & Decision \\
\hline $\begin{array}{l}\text { Treatment condition group and non-treatment condition group before } \\
\text { the application of games }\end{array}$ & .000 & 1.00 & Not Significant & Accept Ho \\
\hline Treatment condition group before and after the application of games & 12.988 & .000 & Significant & Reject Ho \\
\hline $\begin{array}{l}\text { Non-treatment condition group before and after the application of } \\
\text { games }\end{array}$ & 5.047 & .000 & Significant & Reject Ho \\
\hline $\begin{array}{l}\text { Treatment condition and non-treatment group after the application of } \\
\text { games }\end{array}$ & 2.266 & .028 & Significant & Reject Ho \\
\hline
\end{tabular}

There is a significant difference in the performance of the treatment condition group before the application of educational games and after they were applied as shown in the probability values of .000 which is less than the level of significance at .05 . There is a significant difference in the performance of the non-treatment condition group before the application of educational games and after they were applied as shown in the probability values of .000 which is less than the level of significance at .05 . There is a significant difference in the performance of the treatment condition and non-treatment condition group after the application of educational games as shown in the probability values of .028 which is less than the level of significance at .05 .

The findings imply that the performances of the two groups have changed after the application of the treatment of condition. The treatment condition group shows greater improvement than the non-treatment condition group after the educational games were applied. This shows that educational games can increase the performance or achievement of the Grade 8 students and create an interactive environment. Also, educational games have a good effect on the motivation and interaction among the students. In relation to this, Schommer-Aikins, Beuchat-Reichardt and Hernández-Pina (2012) proved that students learn through playing, playing implies interaction, and interaction helps in developing language skills.

In addition, games often incorporate logical reasoning, communication, kinesthetic, visual stimulation, and spatial relations. They also include analysis and interpretation of new and old material which makes learning 
concrete. Furthermore, the hands-on experiences are integral to critical learning, retention, and recall of information acquired in the process. Games started to be understood as an opportunity to check how the students work in real-time, how to increase their participation and motivation either individually or as a member of a team, and part of a lecture was improved in terms of effectiveness in learning (Carrasco, Castellanos, and Viloria, 2019). Games maximize the learners' participation in language learning; while playing games, they subconsciously learn language.

Problem Number 3. What is the level of effectiveness of educational games in language learning of Grade 8 students in English as assessed by the teachers and students?

One of the objectives of the study was to determine the effectiveness of educational games in language learning of Grade 8 students in English. Results of a conducted inquiry on these matters are shown in the following tables. Table 3 shows the level of effectiveness of educational games in language learning of Grade 8 students in English as assessed by the teachers and students. The general composite assessment is $\mathbf{3 . 7 3}$ and interpreted as Highly Effective. The indicator Games promote cooperation, collaboration, and teamwork among students had the highest composite mean which is $\mathbf{3 . 8 2}$ and interpreted as Highly Effective. The indicator that said students find games as informative in the English class had the least composite mean which is $\mathbf{3 . 5 1}$ and interpreted as Highly Effective.

The results imply that the level of effectiveness of educational games in language learning of Grade 8 students in English is evident in the assessment of the teachers and students. The findings show that educational games maximize the learners' participation in language learning; they also proved that collaborative learning is possible through educational games. These implications were made true by Lantz (2010) as he stated that collaborative learning occurs when students work together in small groups toward a common goal, creating meaning, and exploring a topic or improving skills. It increases the ability to think critically; enhances student involvement, satisfaction, engagement, and higher-order learning; and encourages students to participate in giving the answer, explaining, and justifying their opinion.

\section{Table 3}

Level of effectiveness of educational games in language learning of grade 8 students in English

\begin{tabular}{|c|c|c|c|c|c|c|}
\hline \multirow{2}{*}{ Indicators } & \multicolumn{2}{|c|}{ Teachers } & \multicolumn{2}{|c|}{ Students } & \multicolumn{2}{|c|}{ Composite } \\
\hline & $\mathrm{X}$ & VI & $\mathrm{X}$ & VI & $\mathrm{X}$ & VI \\
\hline 1. Games made the learning environment fun and engaging in the English class. & 4.00 & $\mathrm{HE}$ & 3.56 & $\mathrm{HE}$ & 3.78 & $\mathrm{HE}$ \\
\hline 2. Games improve my understanding of the covered topics in English. & 4.00 & $\mathrm{HE}$ & 3.33 & $\mathrm{E}$ & 3.67 & $\mathrm{HE}$ \\
\hline 3. Games boost my self-confidence in communicating with others. & 4.00 & $\mathrm{HE}$ & 3.54 & $\mathrm{HE}$ & 3.77 & $\mathrm{HE}$ \\
\hline 4. Gaming is a valuable use of instructional time in English class. & 4.00 & HE & 3.29 & E & 3.65 & $\mathrm{HE}$ \\
\hline 5. Games made learning easier for me. & 4.00 & $\mathrm{HE}$ & 3.48 & $\mathrm{E}$ & 3.74 & $\mathrm{HE}$ \\
\hline 6. Games promote cooperation, collaboration, and teamwork among students. & 4.00 & $\mathrm{HE}$ & 3.65 & $\mathrm{HE}$ & 3.82 & $\mathrm{HE}$ \\
\hline 7. I find games as informative in the English class. & 3.50 & $\mathrm{HE}$ & 3.52 & $\mathrm{HE}$ & 3.51 & $\mathrm{HE}$ \\
\hline 8. Games capture my attention and interest in the English class. & 4.00 & $\mathrm{HE}$ & 3.44 & $\mathrm{E}$ & 3.72 & $\mathrm{HE}$ \\
\hline 9. Games stimulate my creativity in the English class. & 4.00 & $\mathrm{HE}$ & 3.46 & $\mathrm{E}$ & 3.73 & $\mathrm{HE}$ \\
\hline 10. Games enhance my independent thinking in the English class. & 4.00 & $\mathrm{HE}$ & 3.63 & $\mathrm{HE}$ & 3.81 & $\mathrm{HE}$ \\
\hline 11. Games enhance my speaking skills. & 3.75 & HE & 3.54 & $\mathrm{HE}$ & 3.65 & $\mathrm{HE}$ \\
\hline 12. Games enhance my vocabulary repertoire. & 4.00 & HE & 3.48 & $\mathrm{E}$ & 3.74 & $\mathrm{HE}$ \\
\hline 13. Games enhance my analytical skills in the English class. & 4.00 & $\mathrm{HE}$ & 3.54 & $\mathrm{HE}$ & 3.77 & $\mathrm{HE}$ \\
\hline 14. Games enhance my critical thinking skills in the English class. & 4.00 & $\mathrm{HE}$ & 3.56 & $\mathrm{HE}$ & 3.78 & $\mathrm{HE}$ \\
\hline General Assessment & 3.95 & $\mathrm{HE}$ & 3.50 & $\mathrm{HE}$ & 3.73 & $\mathrm{HE}$ \\
\hline
\end{tabular}

Moreover, the learners in collaborative learning do the things easier and quicker by saving their time, stress, and energy while they perform these tasks in groups. When the learners participate in groups in collaborative learning, the motivation of the learners is heightened, and the learners feel more comfortable and independent while doing the tasks. The learners also find self-satisfaction as they do the tasks by discussing with the other group members (Rao, 2019). 
Hence, the concept of collaborative learning is somehow concerned with Vygotsky's notion of "zone of proximal development". It contemplates what a learner can do if he/she is helped by peers or adults. By considering this model for learning, educators may consider collaboration to increase learners' awareness of other concepts (Rao, 2019).

Vygotsky's theory has been proven to have huge implications for the understanding of peer collaboration activities (Hogan \& Tudge, 1999 as cited in Sanchez et al., 2019). The Zone of Poximal Development (ZPD) is one of the bases of the Vygotskian framework and it defends the collaboration between same age-group students to take advantage of their common characteristics and mental processes to learn together (Johnson et al., 2016). This way, the students share interpersonal factors through the interaction, and the consequences of that interaction are always positive in terms of learning (Hogan \& Tudge, 1999 as cited in Sánchez et al., 2019).

Problem Number 4. Is there a significant relationship between the level of effectiveness of educational games in language learning and the Grade 8 students' performance after the application of the treatment condition?

Table 4 shows the significant relationship between the level of effectiveness of educational games in language learning and the Grade 8 students' performance after the application of the educational games to the treatment condition group.

\section{Table 4}

Test of significant relationship between the level of effectiveness in language learning and performance

\begin{tabular}{lcccc}
\multicolumn{1}{c}{ Variables } & $\begin{array}{c}\text { Pearson Chi } \\
\text { Square }\end{array}$ & p value & Remarks & Decision \\
\hline $\begin{array}{l}\text { Educational Games and } \\
\text { performance }\end{array}$ & $135.667^{\mathrm{a}}$ & .044 & Significant & Reject Ho \\
\hline
\end{tabular}

Table 4 shows the test of significant relationship between the level of effectiveness of educational games in language learning and the Grade 8 students' performance. There is a significant relationship between the educational Games and the students' performance in English as shown in the probability value of .044 which is less than the level significance .05 , thus the null hypothesis is rejected. It can be concluded that there is a significant relationship in the level of effectiveness of educational games in language learning and the Grade 8 students' performance.

The above-mentioned findings of the study imply that students using games demonstrate better understanding of the language and enjoyment than before not using games. The findings further support the idea that the educational games can be viewed as effective tools in language learning of Grade 8 students. Likewise, using educational games in language learning increases the academic achievement and motivation of students compared to the traditional teaching methods.

This finding was proven by Wright, Betteridge and Buckby (2006 as cited in Zhe, 2012). Since playing games is interactive, games are also communicative in essence, and so using game in English teaching and learning can well realize the fundamental idea of the communicative language teaching approach. Using games is a good way to improve students' various skills, as Wright, Betteridge and Buckby (2006 as cited in Zhe, 2012) said, "Games can be found to give practice in all the skills, in all the stages of the teaching and learning and for many types of communication". In playing language games, students must know and understand the rules of the games, and should be clear about what has been, is being, and will be done or said, and what is more important; they must take some actions - doing or saying something to compete in the games. In doing so, they can practice their skills of listening, speaking, reading, and writing comprehensively.

In addition, games are a welcome break from the usual routine of the language class: they are motivating and challenging; and games provide language practice in the various skills - speaking, writing, listening, and reading. They create a meaningful context for the language use. Games encourage the students to be active in the classroom, entertain them, teach the language naturally, and promote fluency. They should be used because they 
help students see the beauty in a foreign language and not just problems of the foreign language itself. Many advantages of games can overcome the speaking problems. The competition of games gives students a natural opportunity to work together and communicate using English with each other. Furthermore, by integrating playing and learning, they practice the learned linguistic knowledge in a meaningful context.

Problem Number 5. Based on the findings of the study, what compendium of educational games can be used as learning tools in English may be proposed?

Based on the findings of the study, the researcher of the study presents her proposed compendium of educational games that can be used as a learning tool in teaching and learning the English language.

\section{Conclusions/reflections and directions for future use}

After careful and thorough analysis of investigation, the following are the findings of the summarized study based on the gathered data. Performance of the Two Groups of Grade 8 Students Before and After the Application of Educational Games:

$>\quad$ For the Treatment Condition group, the overall mean of the Pre-test was 80.94 which was interpreted as Approaching Proficiency. The overall mean of the Post-test was 91.98 and was interpreted as Advanced.

$>\quad$ For the Non-Treatment Condition group, the overall mean of the Pre-test was $\mathbf{8 0 . 9 4}$ and interpreted as Approaching Proficiency; while the overall mean of Post-test was $\mathbf{8 7 . 7 1}$ and interpreted as Proficient.

Test of Significant Difference in the Performance of the Two Groups of Grade 8 Students Before and After the Treatment Condition was applied:

$>$ There is no significant difference in the performance of the Treatment Condition and the Non-Treatment Condition group before the application of the educational games.

$>$ There is a significant difference in the performance of the Treatment Condition group before and after the application of the educational games as shown in the probability values of .000 which is less than the level of significance at .05 .

$>$ There is a significant difference in the performance of the Non-Treatment Condition group before the application of the educational games and after they were applied as shown in the probability values of .000 which is less than the level of significance at .05 .

$>\quad$ There is a significant difference on the performance of the Treatment Condition and Non-Treatment Condition group after the application of educational games as shown in the probability values of .028 which is less than the level of significance at .05.

Level of Effectiveness of the Educational Games in Language Learning of the Grade 8 Students in English as Assessed by the Teachers and Students

$>\quad$ The general composite assessment is $\mathbf{3 . 7 3}$ and interpreted as Highly Effective.

Test of Significant Relationship between the Level of Effectiveness of Educational Games in Language Learning of the Grade 8 Students' Performance After the Application of the Treatment Condition

$>$ There is a significant relationship between the level of effectiveness of educational games in language learning and the Grade 8 students' performance as shown in the probability value of .044 which is less than the level significance .05; thus, the null hypothesis is rejected. 
The Proposed Compendium of Educational

$>$ A compendium of educational games that could be used as learning tools in English has been developed and is recommended for the perusal of the English teachers in the classroom.

Based on the above-mentioned findings of the study, the following conclusions are drawn. That basically, the students have a good grasp of the English language. They can use it with a little ease both academically and socially. The Treatment Condition group performed better in the traditional method of teaching and learning English before the educational games were applied. And that the Treatment Condition group performed better in the traditional method of teaching and learning English before the educational games were applied.

That there is not much difference between the level of performance of the two groups of students before the educational games were applied. The Treatment Condition group performed better after the educational games were applied. While the Non-Treatment group performed better after the educational games were applied. And the two groups of students performed better after the educational games were applied.

That the teachers had a different perspective of the effectiveness of educational games in language teaching: they are more convinced that the games helped improve the language skills of the students. The students, on the other hand, were a little apprehensive in totally accepting the use of games in language learning for they considered games as activities done for fun and entertainment and have not yet taken them as a serious part of their academics.

That the tools teachers used in language teaching affected the performance of their students; the more interactive and fun the tools were, the better the students learned. And that a compendium of educational games that can be used as learning tools in English needs to be developed and ready for dissemination.

Based on the afore-cited findings and conclusions of the study, the researcher recommends the following: Teachers may help plan and design educational games for the students: games for blended learning since the pandemic has changes the education environment; games focus on structure rather than content but are still linked to the syllabus, textbook, or program; games for diversity which are relevant to a wide range of interests and skills; games addresses the challenges of assessment using scoring rubrics that describe different levels of proficiency; and games counteract the potential negative impact of perception on using them in class.

The school administration and educational authorities may recognize the importance of the use of educational games and encourage teachers to use this method in teaching. Curriculum designers may conduct further studies to identify the impact of educational games. They should consider that textbooks should contain a variety of educational games and teachers must be committed implementing and modifying them to suit different environments.

The compendium of educational games made by the researcher may be used in classroom discussions to help teachers activate the interests of the students in language learning. The findings and conclusions of the study may be used by future researchers who might get inspired to undertake research tackling the problem considered in this study. Moreover, a research on a bigger sample of respondents to elicit more information about their performances and attitudes to improve the educational system and methods is also recommended.

\section{References}

Ahmadi, M. R. (2018). The use of technology in English language learning: A literature review. International Journal of Research in English Education.

Akyol, P. K. (2010). Using educational technology tools to improve language and communication skills of ESL students. Novitas-ROYAL, 4(2), 225-241.

Al Zoubi, S. (2018). The impact of exposure to English language on language acquisition. Journal of Applied Linguistics and Language Research, 5(4), 151-162. 
Attitude of engineering students towards engineering drawing: A case study

Aljohani, M. (2017). Principles of "constructivism" in foreign language teaching. Journal of Literature and Art Studies, 7(1), 97-107.

Alkandari, A. (2016). An evaluation of the impact of gaming technology on learning. University of Salford, Salford, UK.

Amineh, R. J., \& Asl, H. D. (2015). Review of constructivism and social constructivism. Journal of Social Sciences, Literature and Languages, 1(1), 9-16.

Amr, K. (2012). Learning through games: Essential features of an educational game. Instructional design, development and evaluation.

Bagwell, R. (2010). Vocabulary card games. eHow Contributor.

Bhattacharya, M., Mach, N., \& Moallem, M. (2011). Emerging technologies in learning: Impact on cognition and culture. https://www.learntechlib.org/primary/p/39252/

Boyle, S. (2011). Teaching toolkit: An introduction to games based learning. UCD Dublin, Ireland: UCD Teaching and Learning/Resources.

Carrasco, S. A. N., Castellanos, J. C., \& Viloria, E. (2019). Construcción del conocimiento y regulación del aprendizaje en tareas colaborativas asíncronas. Revista de Innovación Educativa, 11(1), 6-23.

Castello, D. (2015). First language acquisition and classroom language learning: Similarities and differences. United Kingdom.

Cengage.

Cheney, R. (2017). Kinesthetic teaching strategies for adults in a lecture setting. Western Oregon University.

Chua, E. R., \& Lidawan, M. W. (2019). Games as effective ESL language classroom strategies: A perspective from English major students. European Journal of Foreign Language Teaching. https://oapub.org/edu/index.php/ejfl/article/view/2366

Constantinescu, R. S. (2012). Learning by playing: Using computer games in teaching English grammar to high school students. eLearning \& Software for Education, 2012(2), 110-115.

Costley, K. C. (2014). The positive effects of technology on teaching and student learning. Arkansas Tech University.

Cox, E. (2019). Experiential learning and learning styles. Oxford Research Encyclopedia, International Studies.

Deguang Zhu, D. (2012). Using games to improve students' communicative ability. Journal of Language Teaching and Research, 3(4), 801-805. https://doi.org/10.4304/jltr.3.4.801-805

Drayton, B., Falk, J. K., Stroud, R., Hobbs, K., \& Hammerman, J. (2010). After installation: Ubiquitous computing and high school science in three experienced, high-technology schools. Journal of Technology, Learning, and Assessment, 9(3), 1-57.

Elliott, S.N., Kratochwill, T. R., LittlefieldCook, J., \& Travers, J. (2000). Educational psychology: Effective teaching, effective learning ( $3^{\text {rd }}$ ed.). McGraw-Hill College.

Ersoz, A. (2000). Six games for the EFL/ESL classroom. The internet TESL Journal, 6(6).

Etikan, I. (2015). Comparison of convenience sampling and purposive sampling. American Journal of Theoretical and Applied Statistics. https://doi.org/10.11648/j.ajtas.20160501.11

Hang, S. (2017). Using games to teach young children English language. Vrije Universiteit Brussel.

Harmer, J. (2001). The practice of English language teaching. Essex, England: Longman.

Horowitz, K. S. (2019). Video games and English as a second language the effect of massive multiplayer online video games on the willingness to communicate and communicative anxiety of college students in Puerto Rico. https://files.eric.ed.gov/fulltext/EJ1220304.pd

https://mydreamarea.wordpress.com/2013/01/05

Huer, J. B. (2015). Future thoughts. Educause Review (July/August), 60-61.

Kiryakova, G. (2014). Gamification in education. Proceedings of $9^{\text {th }}$ International Balkan Education and Science Conference.

Klimova, B. F. (2014). Games in the teaching of English. University of Hradec Kralove, Czech Republic.

Kolb, A. Y., \& Kolb, D. A. (2006). Learning styles and learning spaces: A review of the multidisciplinary application of experiential learning theory in higher education. In R. R. Sims \& S. J. Sims (Eds.), New York. 
Kolb, D. A. (1984). Experiential learning: Experience as the source of learning and development. Englewood Cliffs, NJ: Prentice Hall.

Krashen, S. (1983). The natural approach: Language acquisition in the classroom. Oxford: Pergamon.

McCarthy, M. (2010). Experiential learning theory: From theory to practice. Journal of Business \& Economics Research, 8(5).

Mertler, C. A. (2014). Classroom assessment literacy inventory. Retrieved from http://pareonline.net/htm/v8n22/cali.htm

Michel, H. (2016). Characterizing serious games implementation's strategies: Is higher education the new playground of serious games? Institute of Electrical and Electronics Engineers (IEEE).

Milczynski, K. (2011). Literature review: Effectiveness of gaming in the classroom.

Mohammed, A. O. (2014). A model for teaching learning methods of geography in the Ethiopian Colleges of Education. Published doctoral thesis.

Mostowfi, S. (2016). Designing playful learning by using educational board game for children in the age range of 7-12: A case study: Recycling and waste separation education board game. Iran University of Medical Sciences

Norhayati, I. (2016). Improving students' speaking proficiency by using speaking board games for elementary students at Eduprana Language Course Palangkaraya Kalimantan Tengah. Jurnal Humaniora Teknologi, 2(1).

Overby, A., \& Jones, B. L. (2015). Virtual LEGOs: Incorporating Minecraft into the Art Education Curriculum. Art Education, 68(1), 21-27.

Patel, C. (2013). Use of multimedia technology in teaching and learning communication skill: An analysis. International Journal of Advancements in Research \& Technology, 2(7), 116-123.

Pourhossein Gilakjani, A. (2014). A detailed analysis over some important issues towards using computer technology into the EFL classrooms. Universal Journal of Educational Research, 2(2), 146-153. https://doi.org/10.13189/ujer.2014.020206

Rao, P. S. (2019). Collaborative learning in English language learning environment. King Faisal University, Al-Hasa, Kingdom of Saudi Arabia. https://doi.org/10.33329/rjelal.7119.330

Resnik, D. (2011). What is ethics in research and why is it important? Retrieved from https://www.niehs.nih.gov/research/resources/bioethics/whatis/index.cfm

Richards, J., \& Rodgers, T (1986). Approaches and methods in language teaching: A description and analysis. Cambridge: Cambridge University Press.

Sánchez et al. (2019). Motivation and learning through peer group and collaborative games. Universidad de Murcia - España.

Sasidharan, A., \& Kok Eng, T. (2013). Pupils' and teachers' perceptions of a language board game, challenge. Universiti Sains Malaysia.

Saunders, M., Lewis, P., \& Thornhill, A. (2012). Research methods for business students (6 ed.). England: Pearson Education Limited.

Savitri, A. S. (2013). The use of language games to improve the students'speaking ability of class VII A of SMP Ma'arif Terpadu Muntilan in the academic year of 2012/2013. Yogyakarta State University.

Savonitti, G. (2018). Entertainment games for teaching English as a second language: Characteristics and potential. International Journal for Innovation Education and Research. http://ijier.net/ijier/article/view/970

Schommer-Aikins, M., Beuchat-Reichardt, M., \& Hernández-Pina, F. (2012). Creencias epistemológicas y de aprendizaje en la formación inicial de profesores. Anales de psicología, 28(2), 465-474.

Şener, S., \& Çokçalışkan, A. (2017). An Investigation between Multiple Intelligences and Learning Styles. Muğla Sitkı Koçman University, Turkey.

Singh, S. (2016). Game based language learning in ESL Classroom: A theoretical perspective. Vibes Publication: International E-Journal for Research in ELT.

Stangor, C. (2011). Research methods for the behavioral sciences (4th ed.). Mountain View, CA: Taylor, D. C., \& Hamdy, H. (2013). Adult learning theories: Implications for learning and teaching in medical 
education. Medical Teacher, 35(11), 1561-1572.

Udosen, A. E., \& Ekpo, U. S. (2016). Instructional games: implications for curriculum and instruction. Equatorial Journal of Education and Curriculum Studies, 1(1), 24-42.

Valenti, M. (2015). Beyond active learning: Transformation of the learning space. EDUCAUSE Review, 50(4).

Vygotsky, L. S. (1978). Mind and society: The development of higher mental processes. Cambridge, MA: Harvard University Press.

Wang, Y. H. (2010). Using communicative language games in teaching and learning English in Taiwanese primary schools. Journal of Engineering Technology and Education, 7(1), 126-142.

Wijayanti, D. N. (2013). Constructivism theory of language teaching and learning.

Yahoui, N. (2012). The effectiveness of language games in improving learners'vocabulary. Biskra: University of Biskra. 
Alcanse, A. M. J., \& Recillo, M. L. B.

132 Consortia Academia Publishing (A partner of Network of Professional Researchers and Educators) 